\title{
Statyba
}

\section{EVALUATION OF WALL-SLAB CONNECTION BEHAVIOUR UNDER EXTREME LATERAL ACTIONS}

Alg. Kudzys \& Alg. Kudzys

To cite this article: Alg. Kudzys \& Alg. Kudzys (1996) EVALUATION OF WALL-SLAB

CONNECTION BEHAVIOUR UNDER EXTREME LATERAL ACTIONS, Statyba, 2:8, 35-44, DOI:

10.1080/13921525.1996.10590170

To link to this article: https://doi.org/10.1080/13921525.1996.10590170

曲 Published online: 01 Nov 2012.

Submit your article to this journal $\pi$

Џ Article views: 747 


\section{EVALUATION OF WALL-SLAB CONNECTION BEHAVIOUR UNDER EXTREME LATERAL ACTIONS}

\section{Alg. Kudzys}

1. Theoretical connection models applied for FEM analysis

Each type of a structural component, e.g. beams, columns, shear walls and slabs, must conform to its own set of code safety requirements for a specified amount of gravity and lateral loadings. During the past two decades much effort has been directed toward developing effective analysis techniques that are able to model overall building composite behaviour [1]. However, our study was concentrated on structural member performance analysis with a view of comparing the experimental behaviour of the wall-slab connections with the theoretical one predicted by the non-linear finite element analysis (Fig. 1 and Table 1). The experimentally determined cross-section geometry, geometric imperfections, stress-strain behaviour and joint stiffness were all modelled accurately in the non-linear analysis.

Four types of finite elements (concrete, reinforcement, bond-link and crack-link) were chosen for consideration.

Concrete finite elements consisted of 8 nodal points quadrangle elements which orthotropic material model by Darwin and Pecknold [2] was based on the concept of the equivalent uniaxial strain and failure behaviour and was modelled according to Kupfer and Gerstle [3].

Reinforcement linear elements were based on the tri-linear Shima model for the steel stress-strain relationship determination [4].

Reinforcement and concrete bond elements were bond-link ones chosen for two different bond conditions.
Table 1. Finite element distribution in wall-slab connection models

\begin{tabular}{|c|c|c|c|c|}
\hline \multicolumn{5}{|c|}{ Model type and amount of finite elements } \\
\hline Model type & 1 & 2 & 3,4 & 5 \\
\hline Concrete FE & 102 & 102 & 102 & 102 \\
\hline Reinforcement FE & 86 & 90 & 90 & 94 \\
\hline Bond-link FE & 18 & 20 & 44 & 48 \\
\hline Crack-link FE & 20 & 20 & 20 & 20 \\
\hline Total nodal points & 401 & 407 & 431 & 439 \\
\hline
\end{tabular}

The bond of materials in the connection joint core was based on Fujii cycle loading stress-slip relationship [5] and bond in the slab was formed by Morita-Kaku [6] or Kokusho [7] stress-slip principle. The bond stress-slip and reinforcement model characteristics for the slab reinforcement are presented in Table 2 . The bond of materials for the wall and precast slab reinforcement on the basis of experimental evidence was accepted as absolutely perfect.

Table 2. Bond characteristics for slab reinforcement

\begin{tabular}{|c|c|c|c|c|}
\hline Units & \multicolumn{2}{|c|}{$\mathrm{MPa}$} & \multicolumn{2}{c|}{$\mathrm{MPa}$} \\
\hline Characteristic & $\tau_{\mathrm{A}}$ & $\tau_{\mathrm{y}}$ & $\mathrm{E}_{1}$ & $\mathrm{E}_{2}$ \\
\hline $\begin{array}{c}\text { Slab reinforcement in } \\
\text { span }\end{array}$ & 3.05 & 6.10 & 815 & 81.5 \\
\hline $\begin{array}{c}\text { Slab reinforcement in } \\
\text { joint core }\end{array}$ & 13.45 & 17.33 & 2100 & 390 \\
\hline $\begin{array}{c}\text { Precast slab bars in } \\
\text { support }\end{array}$ & 5.4 & 10.85 & 108.2 & 54.1 \\
\hline
\end{tabular}


Concrete crack elements (i.e. elements with zero stiffness in tension) were crack-link ones suggested by NgoScordelis-Franklin discrete crack model [8].

Wall-slab connection calculation model (Fig. 1) geometrical parameters were simulated by doubly reinforced specimen in full scale. The mechanical properties $E$ and $v$ of the concrete and reinforcement elements were based on the experiment specimens WSJ-2 and WSJ-6 characteristics [9]. Three types of quadrangle concrete elements were used, besides, with the same wall, joint core and cast-in-situ slab concrete mechanical properties. In regard to the experimental evidence it was assumed two bending cracks would occur, one on each side of the wall member. Crack-link elements were placed at the slab to wall adjoining surfaces. Five different modification types of the connection model were under consideration (Fig. 2).

1. Type 1: For slab longitudinal reinforcement the bond-link elements were located only in the joint core area. There was no precast slab reinforcement anchorage in the wall member in assumption of large crack development between precast slab end and the wall concrete. The main longitudinal reinforcement amount and its position were the same for model types 1, 2, 3 and 5, i.e. the wall plus slab reinforcement was 4D16+4D16 with their cross sectional area $7.6 \mathrm{~cm}^{2}+7.6 \mathrm{~cm}^{2}$.

2. Type 2: The bond-link elements in the main reinforcement were the same like in type 1 , but the precast slabs were supported on the wall member and there was the bond-link in the tensile stress accepted precast slab.

3. Type 3: The bond-link elements in the main reinforcement were placed like in the composite slab model at the distance till slab vertical load point. The precast slab reinforcement bond-link was the same like in modification type 2 .

4. Type 4: The same bond-link elements like in type 3 , but the slab lower reinforcement amount was doubled, i.e. $8 \mathrm{D} 16$ bars with cross sectional area $15.2 \mathrm{~cm}^{2}$ in order to obtain the effect of the slab reinforcement amount on the joint core shear strength.

5. Type 5: The same bond-link element arrangement in the main reinforcement like in type 3 , but the precast slab reinforcement was extended with bond-link elements through the whole wall thickness in order to obtain the effect of the precast slab reinforcement anchorage in the joint core on the connection behaviour.

The boundary conditions, i.e. the wall and slab supporting points were located identically to the experimental conditions. The load was applied as the constant gravity load in the wall and slab members on the basis of the experimental magnitudes and the monotonous lateral wall load was applied by storey drift displacement.

\section{Results of Finite Element Analysis}

Computer simulation of the building wall-slab connection model was done in regard to the cracking and failure performances data obtained from the experimental test of the specimens. Therefore, computed and experimental values were compared at the initial cracking load stage. The storey drift displacement corresponding experiment 1 st cycle $1 / 1000$, storey drift $1 / 200,1 / 100$ and the ultimate bearing capacity corresponding to the 7 th cycle or $1 / 50$ storey drift at the experiment were accepted. On assumption of the wall-slab connection vertical axial symmetry was applied only one the forward direction monotonous loading by connection storey drift displacement and experimental loops envelope curve was accepted for the comparison of the results. For the forward loading, the trends leading to the structural failure and main stress distribution performance for type 3 trends are plotted in Figs 3, 4.

The direction of the principle stresses and the crack development indicated the dominant compressive stress performance in the joint core and development of bending and diagonal cracks (Figs 3 and 4). In comparison with the modification type 1 , the slab deflection was less considerable and the main bending crack width in the precast slab was notably smaller due to supporting of precast slabs on the wall. Therefore, the joint core accepted greater compressive stresses. The enlargement of the lower slab reinforcement stimulated an increase in depth of the slab concrete compression stress block and, consequently, influenced the diagonal concrete strut width increase. Moreover, asymmetry in the composite slab reinforcement arrangement at the upper and lower part of slabs affected the shape of diagonal concrete strut, which became wider at the joint core bottom. As for the cracking behaviour, the slab 


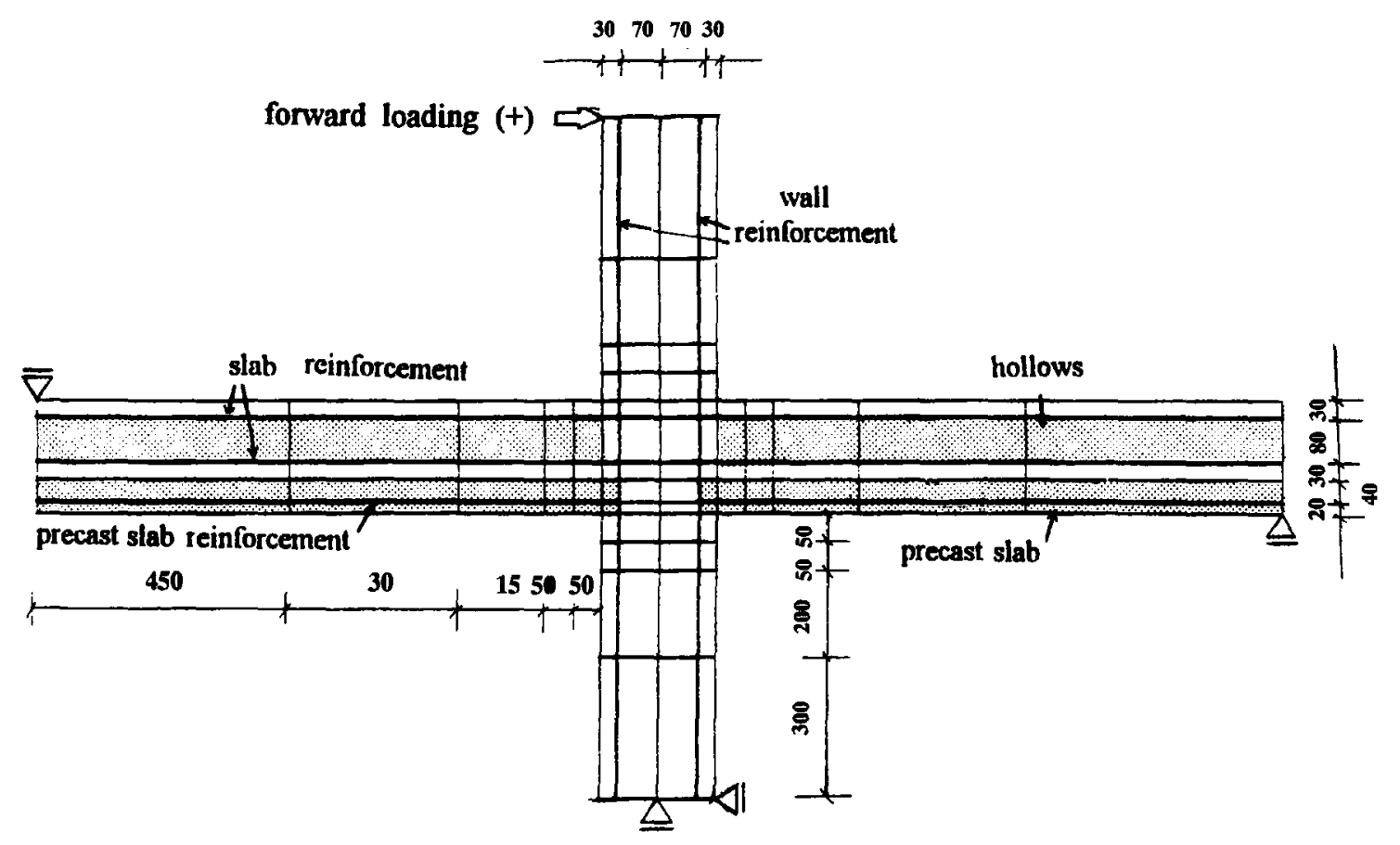

Fig. 1. Wall-slab connection calculation model for finite element analysis

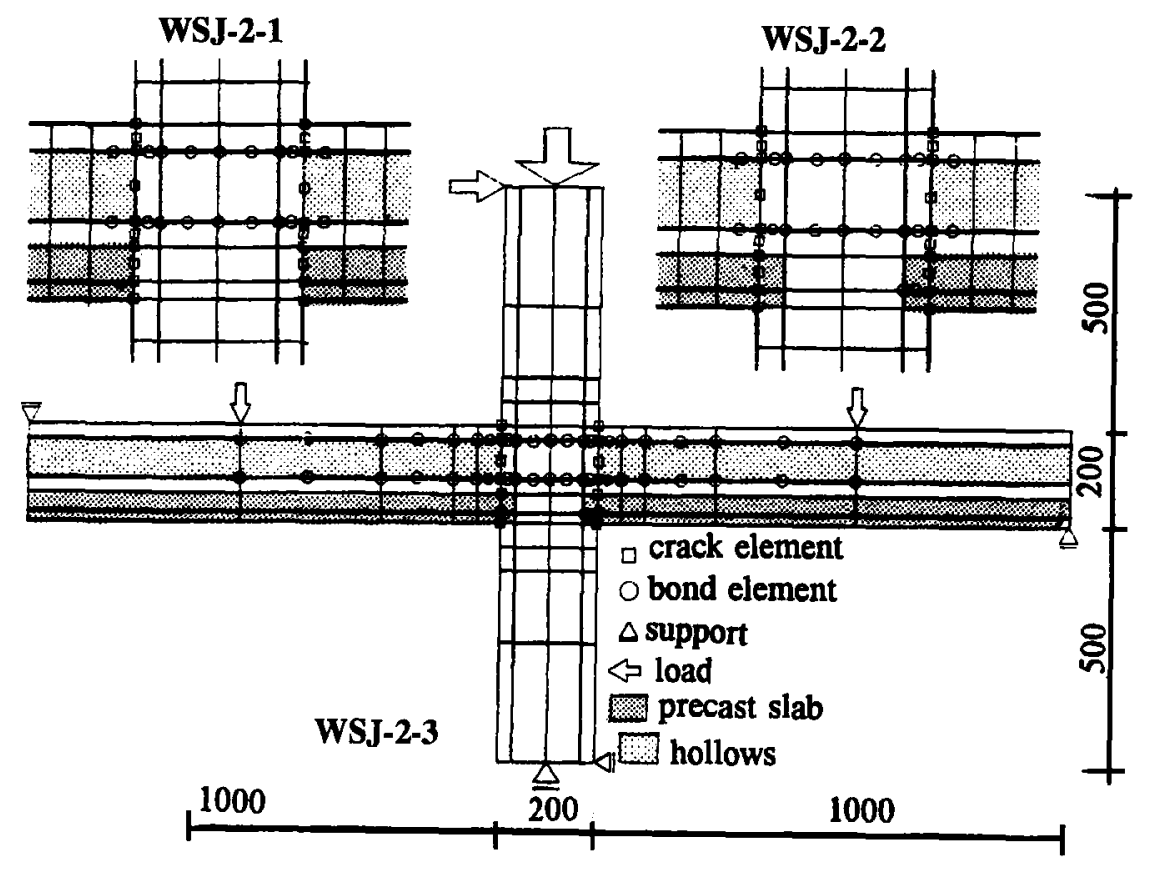

Fig. 2. Crack-link and bond-link elements arrangement in wall-slab connection model:

WSJ-2-1 without and WSJ-2-2 with the precast slab reinforcement anchorage in joint core;

WSJ-2-3 with bond-links till slab loading place (the same model was used for WSJ-2-4 and WSJ-2-5) 


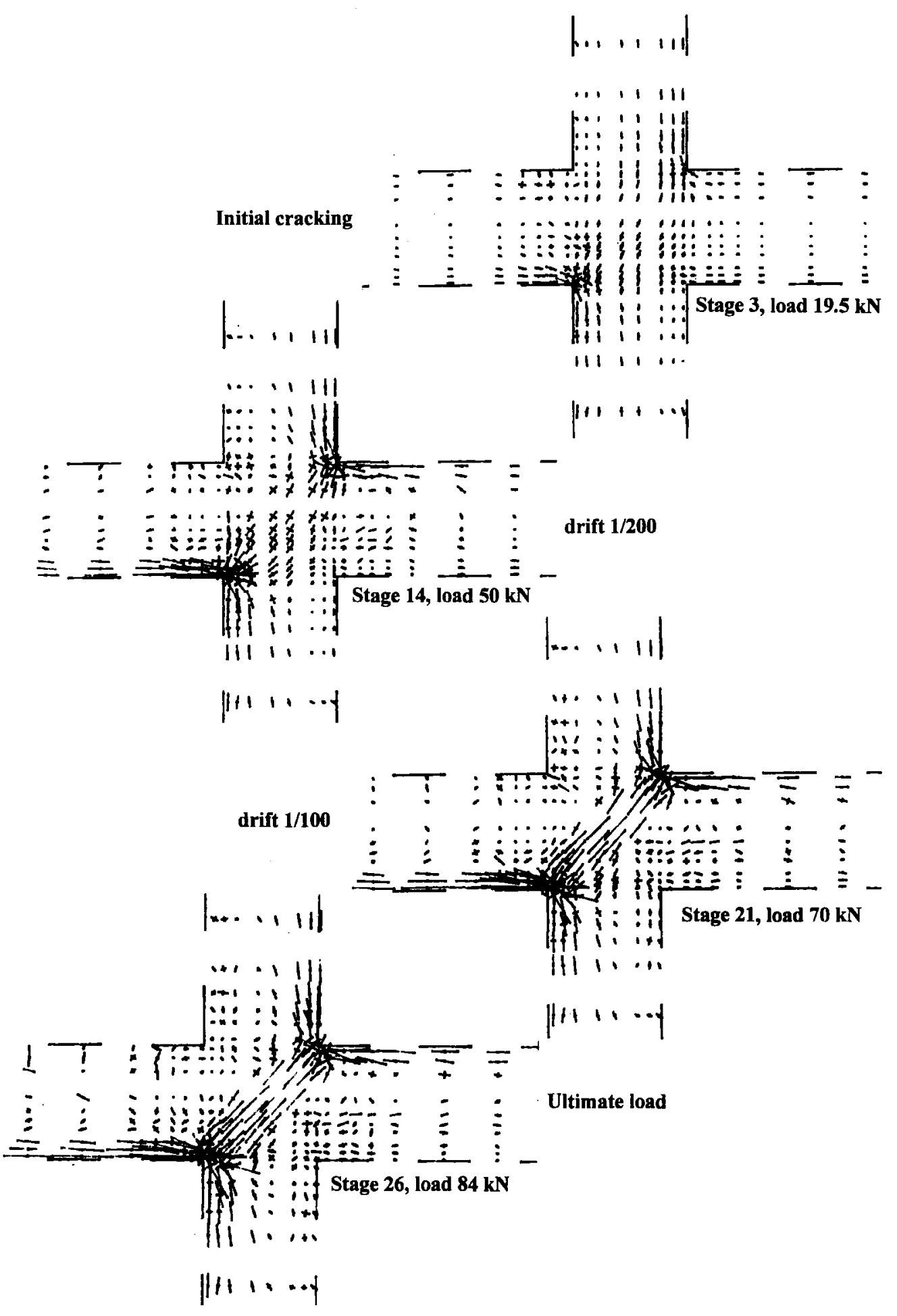

Fig. 3. Main stresses distribution in the specimen WSJ-2-3 


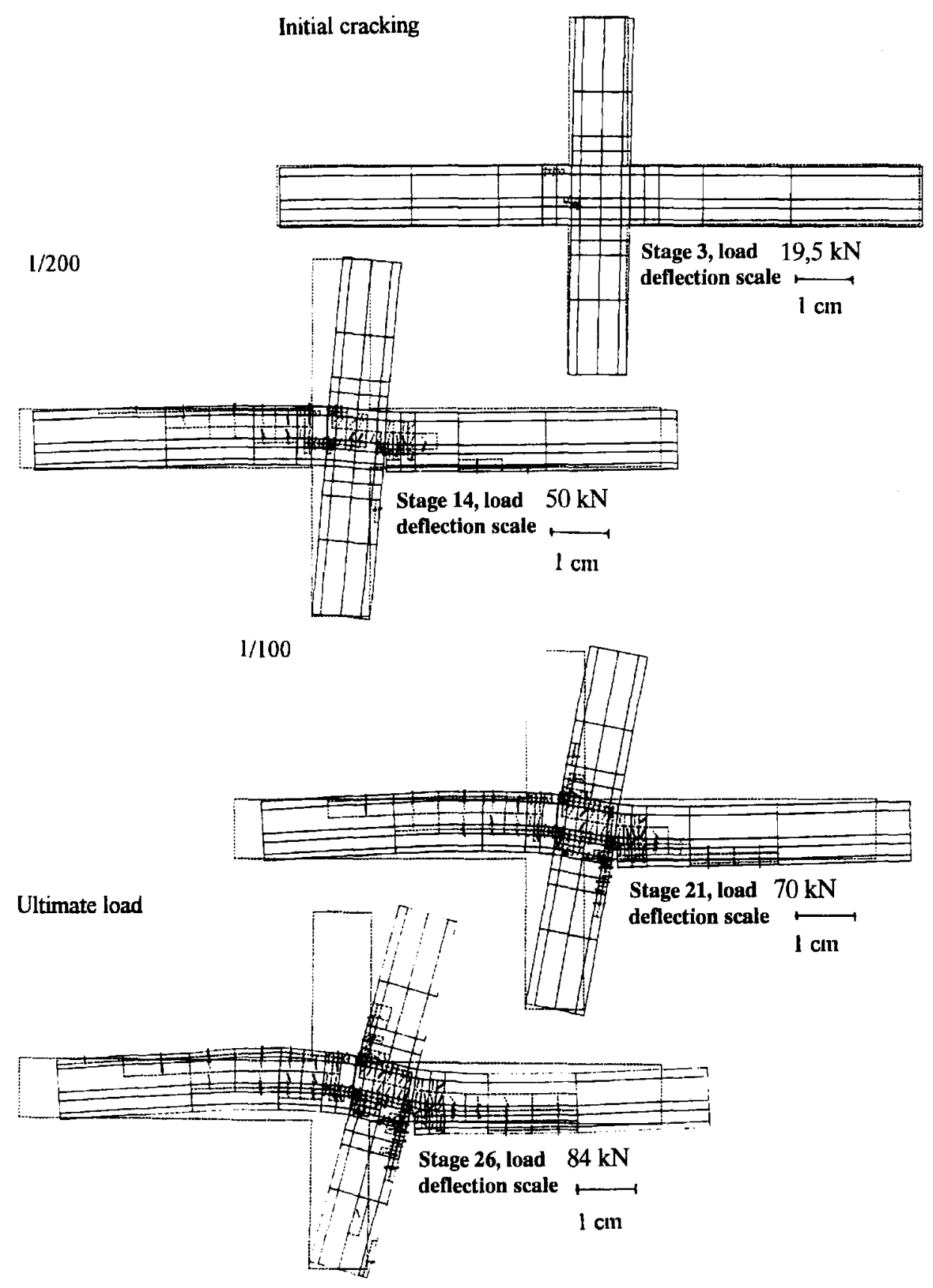

Fig. 4. Cracking development in the specimen WSJ-2-3 
a)
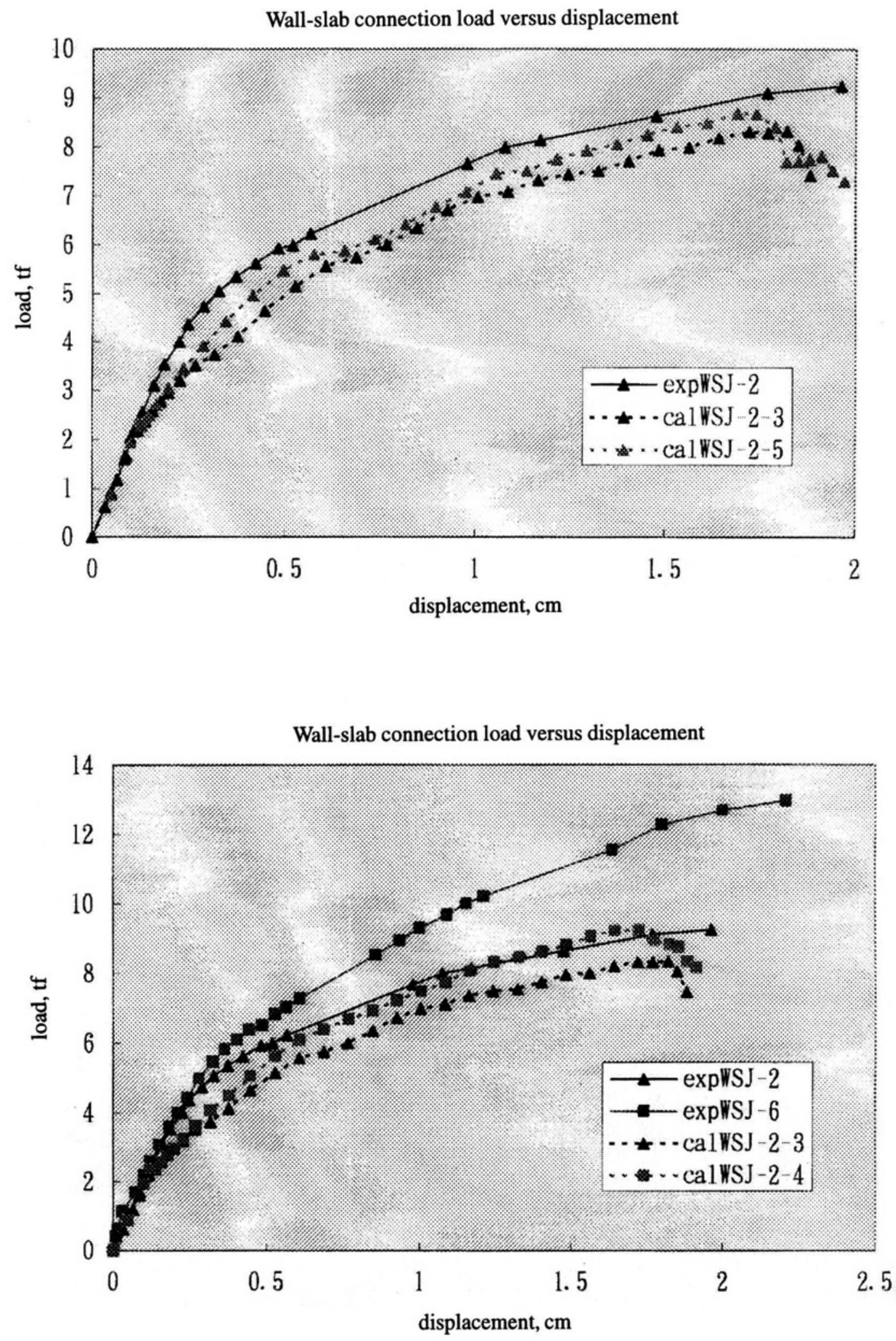

Fig. 5. Experimental versus analytical load-displacement relationship:

a) for specimen WSJ-2 and models WSJ-2-3 and WSJ-2-5;

b) for specimens WSJ-2 and WSJ-6 and models WSJ-2-3 and WSJ-2-4 

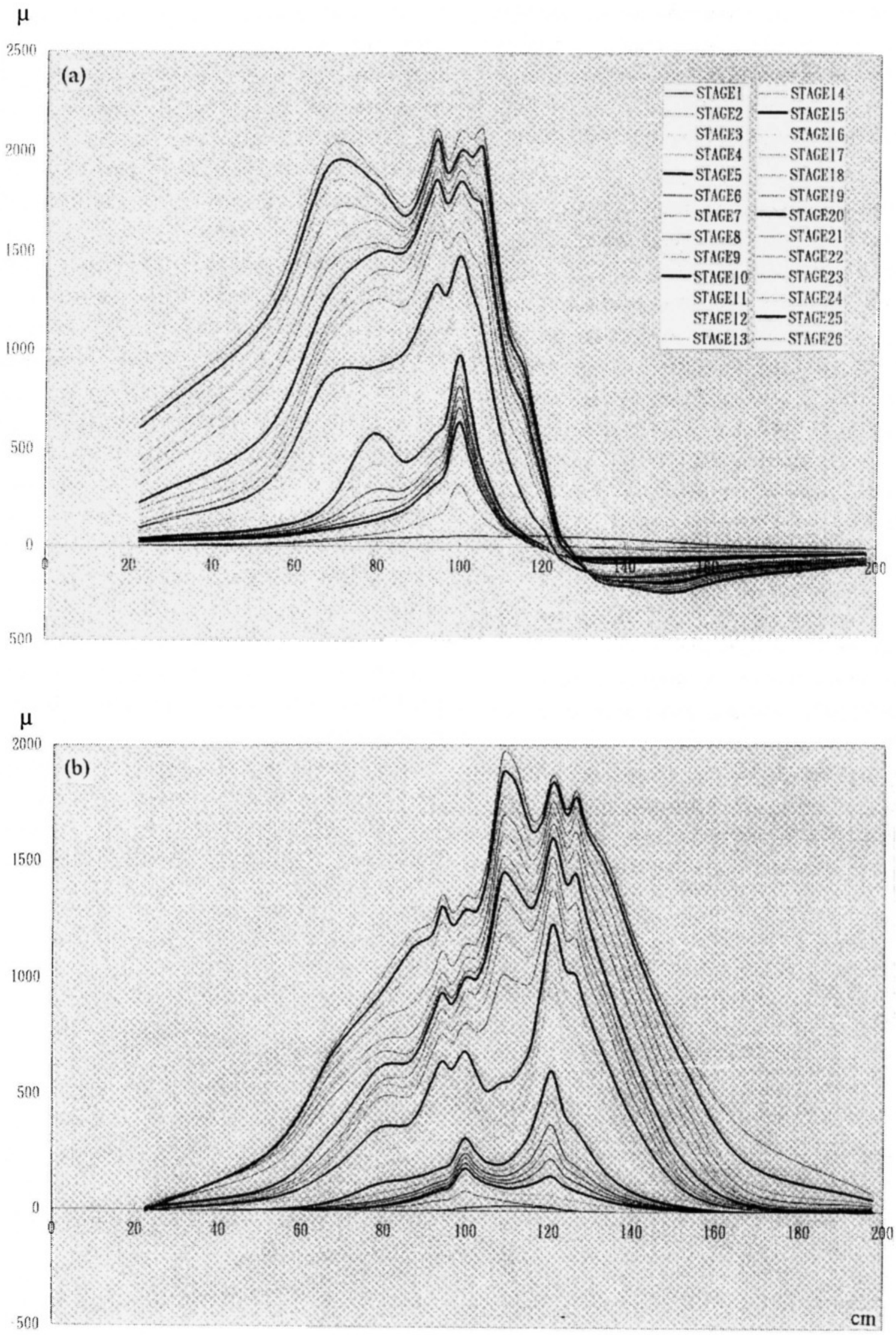

Fig. 6. Strain distribution in model WSJ-2-3 slab upper (a) and lower (b) reinforcement 
bending cracks in the precast and cast- in-situ slabs developed more actively. That resulted in stiffness deterioration and increase in wall and slab deflections.

\section{Comparison of Analytical Data with Test Results}

Analysis of the wall lateral load-displacement relationship curves showed that the ultimate load of the modification type 1 without the precast slab anchorage in the support is significantly lower than that other of types. Furthermore, the slab reinforcement bond-links outside the joint core for the type 3 did not influence the loaddisplacement curve character. Stiffness characteristics in all models were in good agreement with experimental curves before the analytical initial bending cracking point. Later the analytical stiffness deterioration was significant and from the joint core initial shear cracking point analytical curves showed in average $10 \%$ decrease in the load bearing capacity and stiffness at the same time.

The above-mentioned load deterioration was observed in regard to curvatures presented in Fig. 5 analysis. However, the results of the computer simulation on the type 5 model (when the precast slab reinforcement crossed the joint core) showed much better agreement with the experimental data in strength and stiffness performances. Even the calculated ultimate load deterioration value in this modification type decreased insignificantly (about 5\%) comparing to the experimental data.
The additional amount of the lower slab reinforcement influenced the ultimate bearing capacity of connections. Nevertheless, strength increment was not considerable and did not exceed the ultimate bending moment accepted by the wall member. The experimental curve of the heavily reinforced specimen WSJ-6 in the both wall and slab members at the same time showed much stronger performance.

The results of simulation of the strain distribution along the slab longitudinal reinforcement in the modification type 3 are presented in Fig. 6. The strain distribution curves at 3,14,21 and 26 stages correspond to displacement storey drift at the initial bending cracking, $1 / 200,1 / 100$ and at the ultimate load, respectively. Analysis data confirmed our theoretical considerations as well as the results obtained from the electrical strain gauges during the experiment on the lower slab reinforcement performance exceptionally in the tension during the reversal loading. Furthermore, the strain performance shows almost symmetrical distribution in the tension and compression regions. The upper reinforcement acts in the tension area through the joint core and in the opposite slab the tensile strains become considerable.

A comparison of the simulation strain distribution results with the experimental data was made with a view of confirming correctness of the analytical considerations. The additional bond-links in the slab
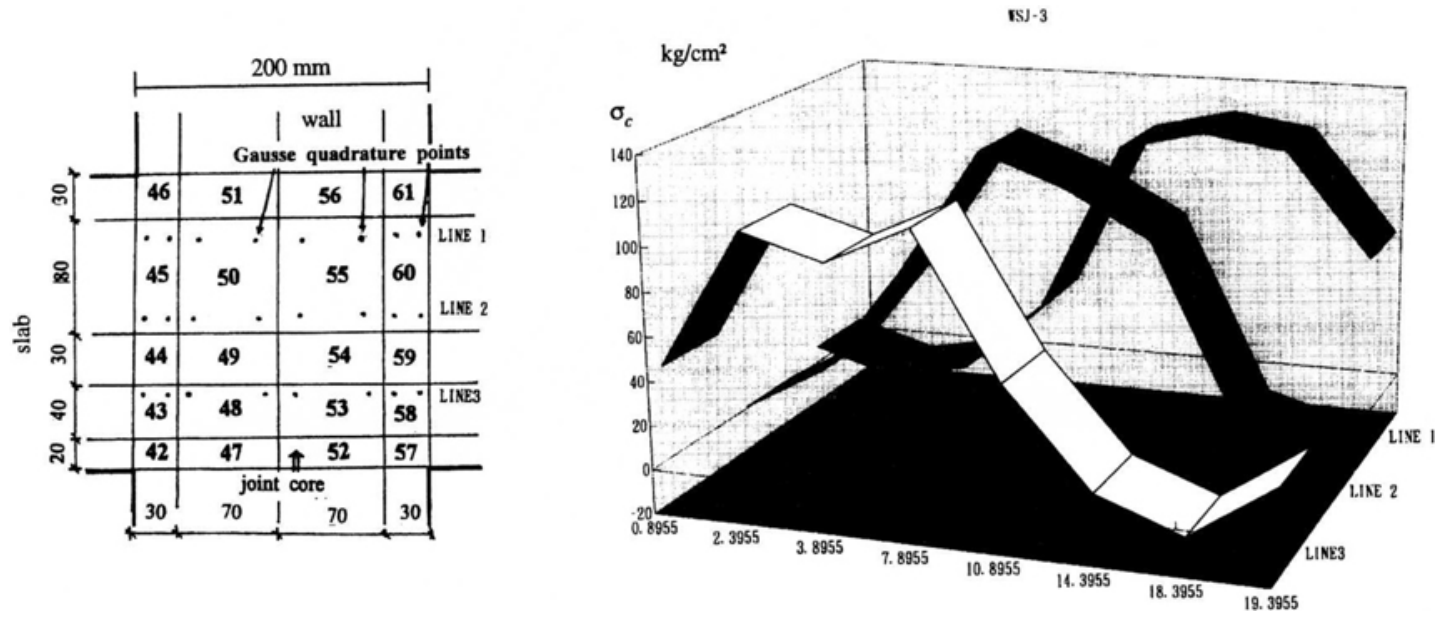

Fig. 7. Gausse quadrature points location and three-dimensional view of compressive stress distribution in the three-joint core sections 
reinforcement did not influence strain distribution, even the strain descend perform more deeply. Simulation results showed unsatisfactory strain distribution comparison results inside the joint core, and encourage an additional and profound study on the bond-link model improvement. The strength behaviour of the joint core is mainly determined by the concrete compression diagonal strut performance. For the wall-composite slab connections, where asymmetrical slabs behaviour in the tension and compression regions influenced the compression strut parameters, the diagonal strut width alternated along the strut. Computer simulation of the compression concrete strut behaviour was done at Gaussian quadrature points in three sections presented in Fig. 7.

When considering the analytical results, it has been confirmed that the compression stress along the diagonal strut is almost constant and its magnitude at the ultimate strength is close to the stress value obtained from analytical compression force. Calculation values of the diagonal strut width by an average of $5-6 \mathrm{~cm}$ sufficiently concur with the simulation data. Greater amount of the slab lower reinforcement to some extent causes an increase in the stress magnitude at the lower part of the diagonal strut.

\section{Conclusions}

1. The flexibility in altering the properties of the structure makes the FEM suitable for studies of reinforced concrete structures connections in which changing material properties and continuous cracking occur under increasing load. Non-linear material properties, non-linear bond slip versus stress relationships, and failure criteria must be adjusted for different type of structures and location of cross-section under consideration.

2. From principal stress distributions, it was concluded that the diagonal compressive strut is predominant in the joint region.

3. Cracking development and failure state of the wall-slab connection models sufficiently concur with experimental results. The main failure in the wall-slab joint core depends on the concrete compression failure in the diagonal concrete strut and the precast slab compression zone at the support portion in the joint corners.
4. The comparison of analytical data with experimental results of load-displacement envelop curves for composite slabs is in sufficient agreement. Nevertheless, the load-displacement curves of the wallslab connection models present a slight strength and stiffness deterioration after bending cracking at the slab ends.

5. Greater amount of slab reinforcement was insufficient for overall connection strength and stiffness increase in connections predicted for joint core failure in shear.

\section{References}

1. J. Bolander and J.K. Wight. Finite Element Modeling of Shear-Wall-Dominant Buildings. Journal of Structural Engineering, ASCE, Vol. 117, No. 6, 1991, p. 1719-1739.

2. Darwin D. and Pecknold D.A. Nonlinear Biaxial StressStrain Law for Concrete. Journal of Engineering Mechanics, Proceedings of ASCE, Vol. 103, No. 2, Apr. 1977, p. 229-241.

3. Kupfer H. and Gerstle K. Behavior of Concrete Under Biaxial Stresses. Journal of the Engineering Mechanics Division, Proceedings of ASCE, Vol. 99, No. EM4, August 1973, p. 852-866.

4. S. Tamai, H. Shima. Average Stress-Average Strain Relationship of Steel in Uniaxial Tension Member in Post-Yielding Range. Summaries of Technical Papers of Civil Engineering Annual Meeting, Architectural Institute of Japan, No. 378, Feb. 1987, p. 239-247 (in Japanese).

5. Fujii S. Study of Reinforced Concrete Bond and Anchorage Characteristics Influence on Structure Performance. Doctoral Thesis, Kyoto University, Jan. 1992, 368p. (in Japanese).

6. Morita S. and Kaku T. Analysis of Bond Characteristics Between Reinforcement and Concrete in Structures Subjected to Reversal Loading. Summaries of Technical Papers of Annual Meeting, Architectural Institute of Japan, No. 229, 1975, p. 15-24 (in Japanese).

7. S. Hayashi, S. Kokusho and H. Yoshida. Experiments of the Bond Behavior Between Deformed Bars and Concrete in the Neighborhood of the Crack. Summaries of Technical Papers of Annual Meeting, Architectural Institute of Japan, No. 348, 1985, p. 86-97 (in Japanese).

8. Ngo D. and Scordelis A.C. Finite Element Analysis of Reinforced Concrete Beams. ACI Journal, Vol. 64, No. 3, March 1967, p. 152-163.

9. Alg. Kudzys, O. Joh and T. Shibata. Seismic Behavior of Reinforced Concrete Wall-Slab Connections Subjected to Vertical and Out-Plane Lateral Loading. Proceedings of the Fifth International Conference on Seismic Zonation, Oct. 1995, Nice, French Rivera, 8 p.

Itteikta 19961127 


\section{EKSTREMALIOMIS HORIZONTALIOMIS APKROVOMIS DEFORMUOJAMU SIENU IR PERDANGUৃ SANDÜROS LAIKYSENOS IVERTINIMAS}

\section{Alg. Kudzys}

\section{S a n tra u k a}

Darbe baigtiniy elementy metodu modeliuojama gelžbetoniniu sienu ir perdangos plokščiu sandūru laikysena ir gauti rezultatai sugretinti su eksperimentiniy tyrimų duomenimis. Modeliavimui naudojami keturiy tipy baigtiniai elementai (betono, armatūros, ryšio ir plyšio). Sieny̨ ir plokščị sandūros geometriniai parametrai bei betono ir armatūros fizinès-mechaninès savybès gautos iš eksperimentiniy duomenu. Penkiy sandüry modeliu kraštinès sạlygos ir plyšiu atsiradimo vietos parinktos iš šiu duomenu.

Nagrinejamų modelių pleišejimo vystymasis ir irimo būdai visiškai atitiko eksperimentinių bandymų rezultatus. Svarbiausiuju itempiu vystymosi analizè parodè, kad dominuoja sandūros zonoje istriža gniuždomo betono prizmè. Išilginès armatūros didinimas perdangos plokštèse sukelia sandūros laikomosios galios praradimą, yrant betonui ịstrižame pjūvyje.
Algirdas KUDZYS. Doctor of Technical sciences (Lithuania), Doctor of Engineering (Japan), Associate Professor, Department of Building Structures, Vilnius Gediminas Technical University (VGTU), 11 Sauletekio Ave, 2040 Vilnius, Lithuania.

Doctoral student, Hokkaido University (Japan) 19901996. Associate Professor (1990), lecturer (1986), assistant (1985), VGTU (formerly VTU, VISI). Publications: author or co-author of more than 40 scientific articles and manuals. Participant of more than 20 conferences. Research interests: joints of reinforced concrete structures, computer simulation and design of reinforced concrete structures, renovation of buildings. 